\title{
Synthesis, Characterization and Biocidal Activity of Cationic Polysaccharide (Extract from Potato) Schiff base Surfactants and their Metal Complexes
}

\author{
M.F. Zaky, A.M. Badawi, I.A. Sabbah", R.A. Abd Elghani", \\ E. A. Ismaeil and M.E. Hendawy" \\ Petrochemicals Department, Egyptian Petroleum Research \\ Institute and *Faculty of Science, Al-Azhar University, Cairo, \\ Egypt.
}

\begin{abstract}
OME cationic polysaccharide Schiff base surfactants and their $N$ metal complexes $\mathrm{Ni}, \mathrm{Cu}, \mathrm{Fe}$, and $\mathrm{Co}$ were synthesized and their chemical structures were confirmed using FTIR, ${ }^{1} \mathrm{HNMR}$ and UV spectroscopic analysis. The surface activities of these suractants were measured, including surface tension $(\gamma)$, critical micelle concentration (CMC), effectiveness $\left(\pi_{\mathrm{cmc}}\right)$, efficiency $\left(\mathrm{Pc}_{20}\right)$, maximum surface excess $\left(\Gamma_{\max }\right)$ and minimum surface area $\left(\mathrm{A}_{\min }\right)$, interfacial tension and emulsification power at $25^{\circ} \mathrm{C}$. Adsorption and micellization free energies of these amphiphiles in their solutions showed a good tendency towards adsorption at the interfaces. Also, the biocidal activity of these Schiff base surfactants and their metal complexes against bacteria (Gram positive and Gram negative) yeast, fungi and also against sulfate reducing bacteria was studied.
\end{abstract}

Keywords: Quaternary ammonium amphiphiles, Micellization, Adsorption, Surface properties polysaccharides, Schiff bases, Metal complexes and Biocidal activity.

A large number of chemical compounds have the ability to inhibit the growth and metabolism of microorganisms ${ }^{(1)}$. For example, solutions of some chemical compounds are used to reduce the microbial flora of the oral cavity. Other chemicals are used to reduce the microbial population in the dust of hospital floors $^{(2)}$. As a result, several classes of chemicals have been identified as anti infective agents against microorganisms ${ }^{(3)}$. Their mode of action depends on the nature of these compounds and the type of the target microorganisms.

Most of cationic surfactants and Schiff bases have ability to inhibit the growth and metabolism of microorganisms ${ }^{(4-6)}$. When the surfactant molecule 
contains Schiff base group the biocidal activity increases than the crosponding surfactant $^{(7)}$. Also, complexation with transition metals leads to increase the ability of these compounds to inhibit the growth of microorganism higher than the uncomplexed bases ${ }^{(8,9)}$.

\section{Materials and Methods}

\section{Chemicals}

Fatty amines (decylamine and octadecylamine) were purchased from Sigma (99\%), aldehydes (4-pyridine carboxaldehyde) purchased from Aldrich (97\%), starch (polysaccharide extract from potato) purchased from Aldrich, sulfuric acid (ADWIC, 99\%), dimethyl formamide (ADWIC, 99\%), ethyl alcohol (ADWIC, 99\%) and paraffin oil (ADWIC, 99\%).

\section{Instrumentation}

Elemental analysis: (Vario Elementar Analyzer); IR spectroscopy: (Perkin Elmer FTIR System) (Genesis Fourier Transform FTIR ${ }^{\mathrm{TM}}$ ) using KBr disks, ${ }^{1} \mathrm{H}$ NMR spectroscopy: (Varian NMR-300, Mercury $300 \mathrm{MHz}$ spectrometers in $\mathrm{CDCl}_{3}$ solvent and TMS as internal standard) and the chemical shifts reported in $\delta$ (ppm), UV (Perkin-Elmer S52 spectrophotometer). Atomic absorption spectroscopy (AAS) was performed using Hitachi 180/80 atomic absorption spectrometer, surface and interfacial tension: (K6-Krüss Tensiometer with platinum ring).

\section{Synthesis}

Sulfation of polysaccharides (extract from potato)

1- A complex reagent was prepared by cooling $50 \mathrm{ml}$ of dimethyl formamide (DMF) in three necked flask immersed in an ice bath $\left(-5^{\circ} \mathrm{C}\right)$. The flask was equipped with a mechanical stirrer, a $\mathrm{CaCl}_{2}$ tube and a dropping funnel, for the addition of the cold chloro sulphonic acid (10 ml.) dropwise during 30-60 min. The reaction was highly exothermic, so the cooling system was kept continuous to maintain the temperature at $\left(-5^{\circ} \mathrm{C}\right)$ for $180 \mathrm{~min}$. The $\mathrm{DMF}-\mathrm{SO}_{3}$ complex was obtained as a yellowish crystalline product.

2- Polysaccharides extracted from potato (100 gm) dried for $3 \mathrm{hr}$ at $\left(110^{\circ} \mathrm{C}\right)$, was mixed with $700 \mathrm{ml}$ of DMF and kept for 2 days at $25^{\circ} \mathrm{C}$. The mixture was cooled for $12 \mathrm{hr}$ and the DMF-SO $\mathrm{SO}_{3}$ complex was added dropwise during stirring, then the mixture was cooled at $\left(-5^{\circ} \mathrm{C}\right)$. The total reaction time was about $3 \mathrm{hr}$.

3- The reaction mixture was then poured to ice and filtered through a Buchner funnel. The product was precipitated by pouring the solution slowly onto one volume of methanol and was pressed out and dried to give polysaccharide sulfate (Fig. 1) ${ }^{(10)}$. 
Chemical structure of polysaccharide sulfate was confirmed using:

1- FTIR which showed bands at $3420 \mathrm{~cm}^{-1},\left(2927 \mathrm{~cm}^{-1}\right.$ and $\left.1060 \mathrm{~cm}^{-1}\right)$, (1124-1152) $\mathrm{cm}^{-1}$ and (612-653) $\mathrm{cm}^{-1}$ corresponding to $\mathrm{OH}$ group, ether group, $\mathrm{S}=\mathrm{O}$, and $\mathrm{S}-\mathrm{O}$, respectively.

2- ${ }^{1} \mathrm{H}-\mathrm{NMR}$ which showed signals at $\delta 2.1 \mathrm{ppm}(\mathrm{s}, \mathrm{O} \underline{\mathrm{H}}), 4.2(\mathrm{~d}$, $\left.\mathrm{HOC} \underline{\mathrm{HCHOCH}}{ }_{2} \mathrm{OH}\right), 3.8 \mathrm{ppm}(\mathrm{d}, \underline{\mathrm{CHO}})$ and $3.6 \mathrm{ppm}\left(\mathrm{d}, \underline{\mathrm{C}}_{2} \mathrm{OH}\right)$.

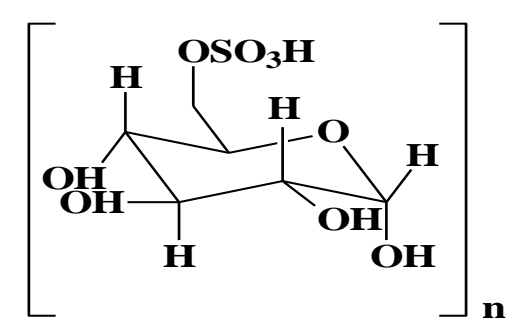

Fig. 1. Structure of polysaccharide sulfate.

Synthesis of decyl amine-4-pyridine carboxaldehyde

A solution of decyl amine (7.8 gm, 0.05 mole) and 4-pyridine carboxaldehyde (5.3 gm, 0.05 mole) was mixed. The mixture was refluxed in ethanol for $4 \mathrm{hr}$ and then left to stand over night and then filtered. ${ }^{(11)}$ The product was recrystallized three times from ethanol and dried in a vacuum oven at $40^{\circ} \mathrm{C}$ to afford pale yellow crystals $\left(\mathrm{Q}_{10}\right)$ (Fig. 2) yield 90\%, m.p.= $\left(97-98^{\circ} \mathrm{C}\right), 77.45 \%$ (C), $10.23 \%(\mathrm{H})$ and $11.21 \%(\mathrm{~N})$.

Chemical structure of decyl amine-4-pyridine carboxaldehyde was confirmed using FTIR which showed bands at $1635-1660 \mathrm{~cm}^{-1}, 2920 \mathrm{~cm}^{-1}, 2850 \mathrm{~cm}^{-1}$ and 935-987 $\mathrm{cm}^{-1}$ corresponding to $\mathrm{C}=\mathrm{N}, \mathrm{CH}_{2}$ groups, $\mathrm{CH}_{3}$ groups and $\mathrm{C}-\mathrm{H}$ aromatic.

Synthesis of octadecyl amine-4-pyridine carboxaldehyde

A solution of octadecyl amine (13.4 gm, 0.05 mole) and 4-pyridine carboxaldehyde (5.3 gm, 0.05 mole) was mixed. The mixture was refluxed in ethanol for $12 \mathrm{hr}$ and then left to stand over night and then filtered. The product was recrystallized three times from ethanol and dried in a vacuum oven at $40^{\circ} \mathrm{C}$ to afford pale yellow crystals $\left(\mathrm{Q}_{18}\right)$ (Fig. 2) yield $77 \%$ and m.p.= $\left(118-119^{\circ} \mathrm{C}\right)$, $79.89 \%(\mathrm{C}), 11.72 \%(\mathrm{H})$ and $7.74 \%(\mathrm{~N})$.

Chemical structure of octadecyl amine-4-pyridine carboxaldehyde was confirmed using FTIR which showed bands at 1635-1660 $\mathrm{cm}^{-1}, 2920 \mathrm{~cm}^{-1}, 2850$ $\mathrm{cm}^{-1}$ and $935-987 \mathrm{~cm}^{-1}$ corresponding to $\mathrm{C}=\mathrm{N}, \mathrm{CH}_{2}$ groups, $\mathrm{CH}_{3}$ groups and $\mathrm{C}-\mathrm{H}$ stretching of the aromatic pyridine nucleus. 


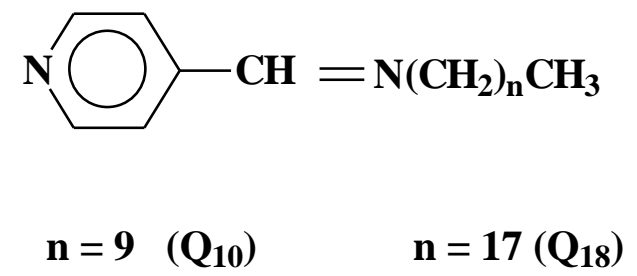

Fig. 2. Structure of decyl amine-4-pyridine carboxaldehyde $\left(Q_{10}\right)$ and octadecyl amine-4-pyridine carboxaldehyde $\left(Q_{18}\right)$.

Synthesis of decyl amine-4-pyridine carboxaldehyde, polysaccharide sulfate

To a mixture of 4-decyl amine pyridine carboxaldehyde Schiff base (1.4 gm, $\left.5.5 \times 10^{-3} \mathrm{~mole}\right)$, polysaccharide potato sulfate $\left(10 \mathrm{gm}, 1.35 \times 10^{-3} \mathrm{~mole}\right)$ was added and in presence of $200 \mathrm{ml}$ of methanol. The mixture was refluxed for $12 \mathrm{hr}$ and then left to stand over night. The product filtered off to remove the unreacted materials $^{(12)}$. The crystallization by methanol afforded 4-decyl amine pyridine polysaccharide sulfate $\left(\mathrm{BQ}_{10}\right)($ Fig. 3$)$ yield $83 \%$ and m.p. $=\left(137-138^{\circ} \mathrm{C}\right)$. sulfate

Synthesis of octadecyl amine-4-pyridine carboxaldehyde, polysaccharide

To a mixture of 4-octadecyl amine pyridine carboxaldehyde Schiff base ( $\left.2 \mathrm{gm}, 5.5 \times 10^{-3} \mathrm{~mole}\right)$, polysaccharide potato sulfate $\left(10 \mathrm{gm}, 1.35 \times 10^{-3}\right.$ mole $)$ was added and in presence of $200 \mathrm{ml}$ of ethanol. The mixture was refluxed for 22 $\mathrm{hr}$ and then left to stand over night. The product was filtered off to remove the unreacted materials. The crystalization by methanol afforded 4-octadecyl amine pyridine polysaccharide sulfate $\left(\mathrm{BQ}_{18}\right)$ (Fig. 3) yield $61 \%$ and m.p.= $\left(179-181^{\circ} \mathrm{C}\right)$.

Chemical structurs of decyl amine-4-pyridine carboxaldehyde, polysaccharide sulfate and octadecyl amine-4-pyridine carboxaldehyde, polysaccharide sulfate were confirmed using:

1- FTIR which showed bands at (1635-1660) $\mathrm{cm}^{-1}, 2920 \mathrm{~cm}^{-1}, 2850 \mathrm{~cm}^{-1}$, $927 \mathrm{~cm}^{-1}, 1020 \mathrm{~cm}^{-1},(1114-1150) \mathrm{cm}^{-1}, 620 \mathrm{~cm}^{-1}$ and two bands at (3130 and 1450) $\mathrm{cm}^{-1}$ corresponding to $\mathrm{C}=\mathrm{N}, \mathrm{CH}_{2}$ groups, $\mathrm{CH}_{3}$ groups, $\mathrm{C}-\mathrm{H}$ stretching of the aromatic pyridine nucleus, ether group, $\mathrm{S}=\mathrm{O}, \mathrm{S}-\mathrm{O}$ and $\left[\mathrm{N}^{+}\right]$group, respectively.

2- ${ }^{1} \mathrm{H}-\mathrm{NMR}$ which showed signals at $8.5 \mathrm{ppm}$ (d, $\underline{\mathrm{CH}}$ aromatic ring), 7.5 $\operatorname{ppm}(\mathrm{s}, \mathrm{CH}=\mathrm{N}), 0.9 \mathrm{ppm}\left(\mathrm{t}, \mathrm{CH}_{3} \mathrm{CH}_{2}\right), 1.2 \mathrm{ppm}\left(\mathrm{m},\left(\mathrm{CH}_{2}\right)_{\mathrm{n}}\right), 5 \mathrm{ppm}(\mathrm{d}, \mathrm{C} \underline{\mathrm{HO}}), 3.5$

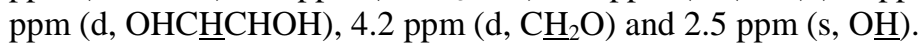




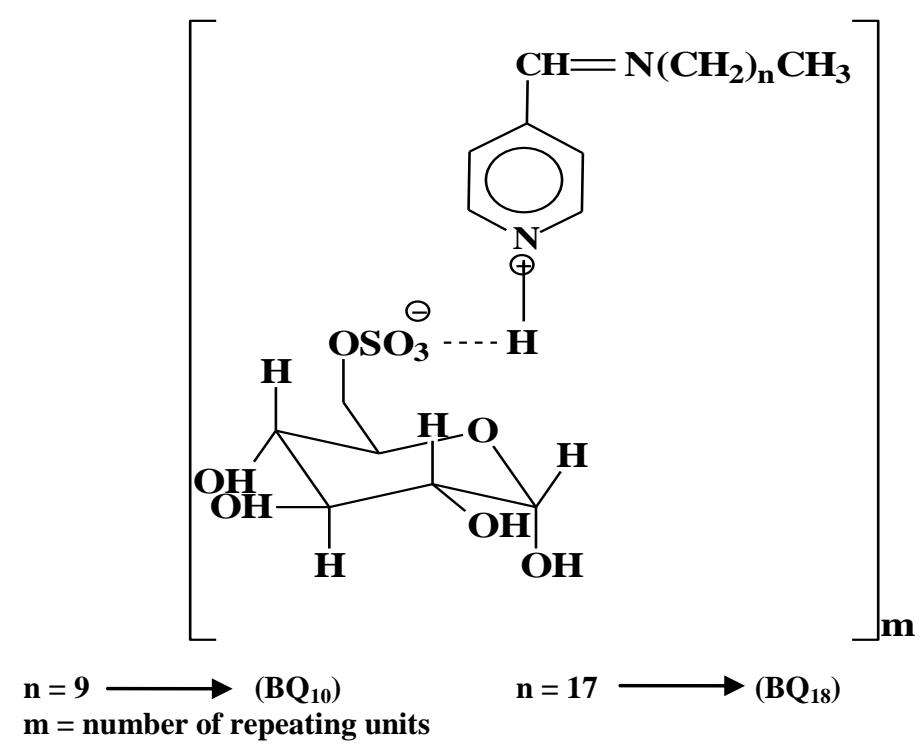

Fig. 3. Structure of decyl amine-4-pyridine carboxaldehyde, polysaccharide sulfate and octadecyl amine-4-pyridine carboxaldehyde, polysaccharide sulfate.

Synthesis of $\mathrm{Ni}$ (II), Co (II), $\mathrm{Fe}$ (III) and/or $\mathrm{Cu}$ (II) metal complexes of decylamine-4-pyridine carboxaldehyde polysaccharide sulfate $\left(B Q_{10}\right)$

To a solution of compound $\left(\mathrm{BQ}_{10}\right)\left(3.6 \times 10^{-4}\right.$ mole $)$ in ethanol $(100 \mathrm{ml})$ a solution of anhydrous $\mathrm{NiCl}_{2}\left(7.2 \times 10^{-4}\right.$ mole $), \mathrm{CoCl}_{2} \cdot 6 \mathrm{H}_{2} \mathrm{O}\left(7.2 \times 10^{-4}\right.$ mole $)$, $\mathrm{FeCl}_{3}\left(7.2 \times 10^{-4}\right.$ mole $)$ and/or $\mathrm{CuSO}_{4}\left(7.2 \times 10^{-4}\right.$ mole $)$ in $(50 \mathrm{ml})$ methanol was added separately and heated under reflux for $6 \mathrm{hr}$. The reaction mixture was left overnight to complete the precipitation of the products ${ }^{(13-15)}$. The product was then filtered off and recrystallized twice from methanol to give the yellowish sharp crystalline products of the $\left(\mathrm{BQ}_{10} \mathrm{Ni}\right),\left(\mathrm{BQ}_{10} \mathrm{Co}\right),\left(\mathrm{BQ}_{10} \mathrm{Fe}\right)$ and $\left(\mathrm{BQ}_{10} \mathrm{Cu}\right)$, respectively (Fig. 4). AAS showed $\mathrm{Ni} \%$ (1.11), $\mathrm{Co} \%$ (1.03), $\mathrm{Fe} \%(0.98)$ and $\mathrm{Cu} \%$ (1.15).

Synthesis of Ni (II), Co (II), Fe (III) and/or Cu (II) metal complexes of octadecylamine-4-pyridine carboxaldehyde polysaccharide $\operatorname{sulfate}\left(B Q_{18}\right)$

To a solution of compound $\left(\mathrm{BQ}_{18}\right)\left(3.4 \times 10^{-4}\right.$ mole $)$ in ethanol $(100 \mathrm{ml})$ a solution of anhydrous $\mathrm{NiCl}_{2}\left(6.83 \times 10^{-4}\right.$ mole $), \mathrm{CoCl}_{2} \cdot 6 \mathrm{H}_{2} \mathrm{O}\left(6.83 \times 10^{-4}\right.$ mole $)$, $\mathrm{FeCl}_{3}\left(6.83 \times 10^{-4}\right.$ mole $)$ and/or $\mathrm{CuSO}_{4}\left(6.83 \times 10^{-4}\right.$ mole $)$ in $(50 \mathrm{ml})$ n-propanol was added separately and heated under reflux for $6 \mathrm{hr}$. The reaction mixture was left overnight to complete the precipitation of the products. The product was then filtered off and recrystallized twice from methanol to give the yellowish sharp crystalline products of the $\left(\mathrm{BQ}_{18} \mathrm{Ni}\right),\left(\mathrm{BQ}_{18} \mathrm{Co}\right),\left(\mathrm{BQ}_{18} \mathrm{Fe}\right)$ and $\left(\mathrm{BQ}_{18} \mathrm{Cu}\right)$, respectively (Fig. 4). AAS showed Ni\% (1.02), Co\% (0.97), Fe\% (0.93) and $\mathrm{Cu} \%$ (1.17). 

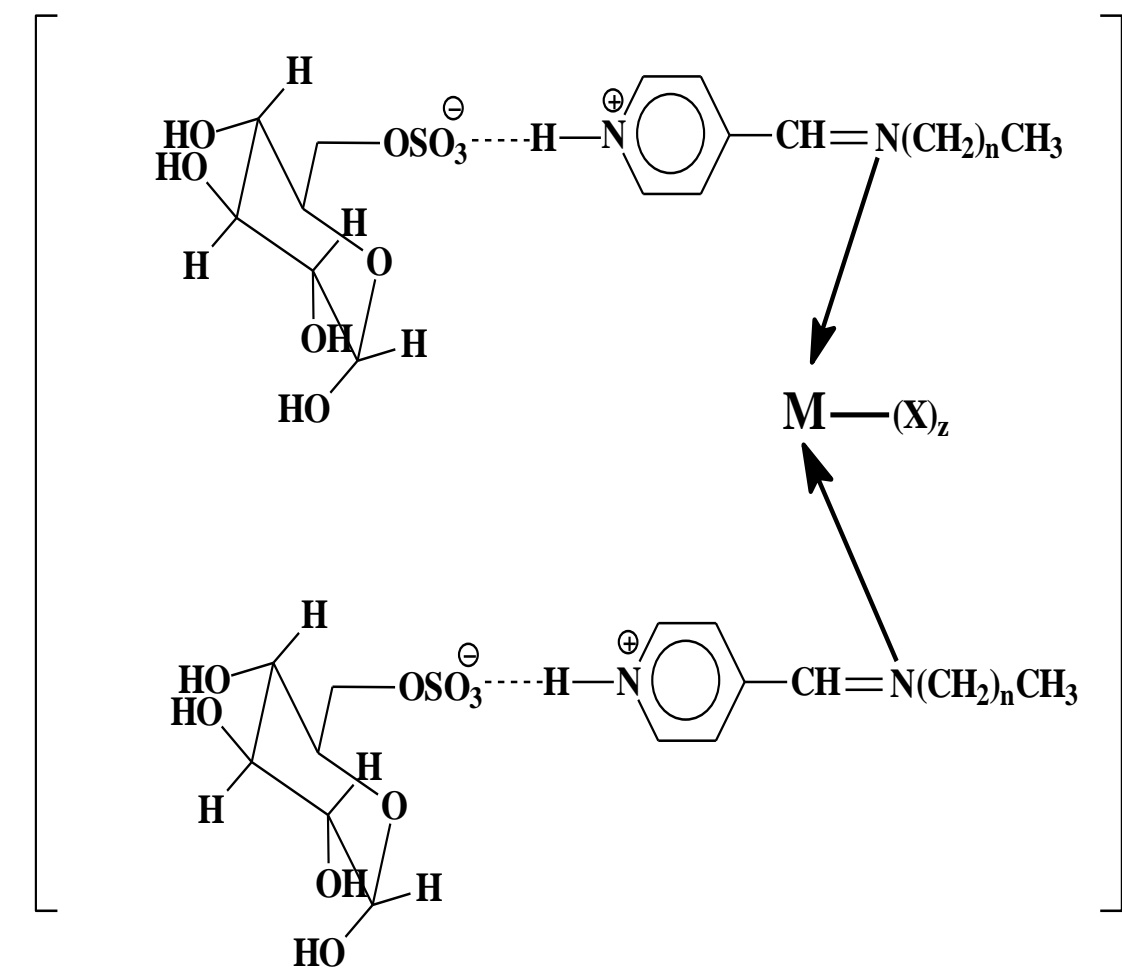

$\mathrm{n}=9$ and 17

$\mathrm{M}=\mathrm{Ni}, \mathrm{Co}, \mathrm{Fe}$ and $\mathrm{Cu}$

m = number of repeating group

$\mathrm{X}=\mathrm{Cl}$ and $\mathrm{SO}_{4}$

$\mathrm{BQ}_{10} \mathrm{Ni}(\mathrm{M}=\mathrm{Ni}, \mathrm{X}=\mathrm{Cl}, \mathrm{z}=2$ and $\mathrm{n}=9) \quad \mathrm{BQ} \mathrm{Q}_{10} \mathrm{Co} \quad(\mathrm{M}=\mathrm{Co}, \mathrm{X}=\mathrm{Cl}, \mathrm{z}=2$ and $\mathrm{n}=9)$

$\mathrm{BQ}_{10} \mathrm{Fe}(\mathrm{M}=\mathrm{Fe}, \mathrm{X}=\mathrm{Cl}, \mathrm{z}=3$ and $\mathrm{n}=9) \quad \mathrm{BQ}_{10} \mathrm{Cu}\left(\left(\mathrm{M}=\mathrm{Cu}, \mathrm{X}=\mathrm{SO}_{4}, \mathrm{z}=1\right.\right.$ and $\left.\mathrm{n}=9\right)$

$\mathrm{BQ}_{18} \mathrm{Ni}(\mathrm{M}=\mathrm{Ni}, \mathrm{X}=\mathrm{Cl}, \mathrm{z}=2$ and $\mathrm{n}=17) \quad \mathrm{BQ}_{18} \mathrm{Co} \quad(\mathrm{M}=\mathrm{Co}, \mathrm{X}=\mathrm{Cl}, \mathrm{z}=2$ and $\mathrm{n}=17$

$\mathrm{BQ}_{18} \mathrm{Fe}(\mathrm{M}=\mathrm{Fe}, \mathrm{X}=\mathrm{Cl}, \mathrm{z}=3$ and $\mathrm{n}=17) \quad \mathrm{BQ}_{18} \mathrm{Cu}\left(\left(\mathrm{M}=\mathrm{Cu}, \mathrm{X}=\mathrm{SO}_{4}, \mathrm{z}=1\right.\right.$ and $\left.\mathrm{n}=17\right)$

Fig. 4. structure of metal complexes of decylamine -4- pyridine carboxaldehyde polysaccharide sulfate $\left(\mathrm{BQ}_{10}\right)$ and octadecylamine -4- pyridine carboxaldehyde polysaccharide sulfate $\left(B Q_{18}\right)$.

\section{Results and Discussion}

Chemical structure

UV spectra

UV spectra were recorded with a Perkin-Elmer S52 spectrophotometer. The quaternization and their metal complexes were confirmed by the appearance of new bands in UV spectra (Table 1). 
TABLE 1. UV adsorption maxima of 4-fatty amine pyridine carboxaldehyde polysaccharide sulfate and their metal complexes.

\begin{tabular}{|c|c|c|c|}
\hline Compound & $\lambda_{\max }(\mathbf{n m})$ & Compound & $\lambda_{\max }(\mathbf{n m})$ \\
\hline $\mathbf{B} \mathbf{Q}_{10}$ & $257.5,203$ & $\mathbf{B Q}_{18}$ & $741.5,225.0,205.0$ \\
\hline $\mathrm{BQ}_{10} \mathrm{Ni}$ & $741.0,257.0,227.5,216.0$ & $\mathrm{BQ}_{18} \mathrm{Ni}$ & $741.5,260.5,229.5$ \\
\hline $\mathrm{BQ}_{10} \mathrm{Co}$ & $739.0,256.0,230.0$ & $\mathrm{BQ}_{18} \mathrm{Co}$ & $740.5,252.0,229.5$ \\
\hline $\mathrm{BQ}_{10} \mathrm{Fe}$ & $740.5,257.0,229.5$ & $\mathrm{BQ}_{18} \mathrm{Fe}$ & $841.0,737.0,252.0,229.0$ \\
\hline $\mathrm{BQ}_{10} \mathrm{Cu}$ & $739.5,256.0,229.5$ & $\mathrm{BQ}_{18} \mathrm{Cu}$ & $741.5,254.5,229.5$ \\
\hline
\end{tabular}

\section{Measurements}

Surface tension $(\gamma)$ and critical micelle concentration (CMC)

Surface tension is a characteristic property for the liquids. That phenomenon appeared originally from the attraction between the molecules at the surface. The surface tension value of the bidistilled water at $25^{\circ} \mathrm{C}$ formed $71.8 \mathrm{mN} / \mathrm{m}$ which is attributed to the attraction forces between water molecules at the water surface due to the hydrogen bonds.

If any foreign molecules present at the water surface, that results in disturbing that tension leading to decrease it to lower values. Meanwhile, surfactant molecules tend to be adsorbed at the air - water interface at lower concentration. Hence, by increasing the surfactant concentration, the surface tension of the resulted solution decreased generally.

Figure 5 represents the relation between the surface tension values in $(\mathrm{mN} / \mathrm{m})$ and the concentration $(\log \mathrm{C})$ at $25^{\circ} \mathrm{C}$.

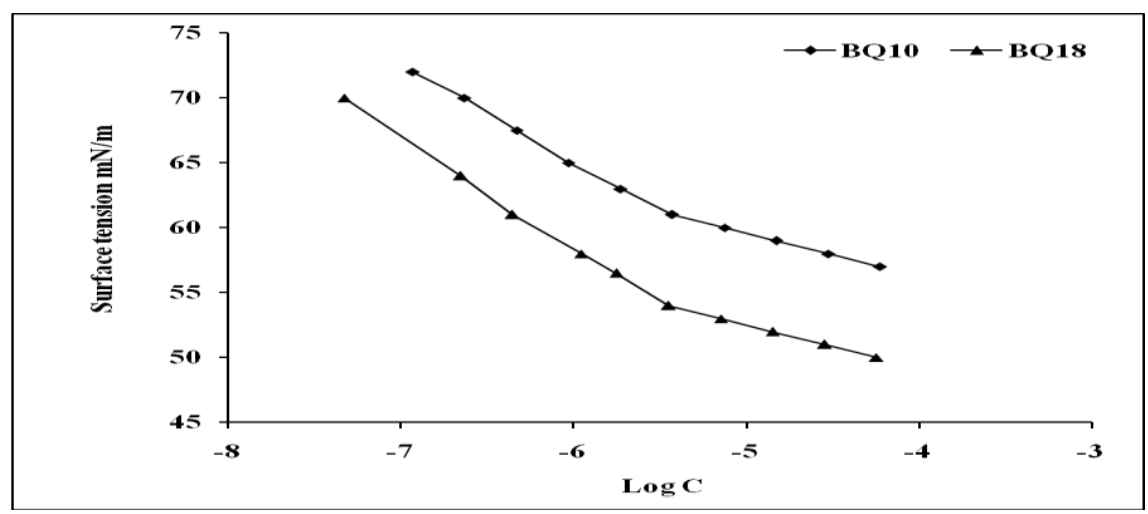

Fig. 5. Variation of surface tension against concentration of the synthesized quaternary ammonium Schiff bases. 
These curves are characterized by two regions, one at lower concentration at which surface tension is greatly sensitive towards concentration reaction, the other at which the surface tension is almost constant up on variation of surfactant concentration. Extrapolation of these two regions determines the so-called critical micelle concentration $(\mathrm{CMC})^{(16,17)}$.

The critical micelle concentration is defined as the concentration of the surfactant at which no further decrease in the surface tension could be obtained upon addition of any further amounts of surfactant in the solution. There is equilibrium between the singly adsorbed surfactant molecules at the interface and the micellized surfactant molecules. That equilibrium occurred at the concentration of complete surface tension (CMC) ${ }^{(18,19)}$. The micelle formation is the most vital point of view in the surfactant fundamental, because it is the most effective geometrical arrangement of the molecules at the desired concentrations of the synthesized surfactants given from their surface tension isotherms listed in Table 2.

TABLE 2. Surface properties of the synthesized Schiff base amphiphiles in bidistilled water at $25^{\circ} \mathrm{C}$.

\begin{tabular}{|c|c|c|c|c|c|}
\hline Compound & $\begin{array}{c}\text { CMC, } \\
\text { mole/Lx10-7 }\end{array}$ & $\begin{array}{c}\boldsymbol{\gamma}_{\text {cmc, }} \\
\mathbf{m N} / \mathbf{m}\end{array}$ & $\begin{array}{c}\boldsymbol{\pi}_{\text {cmc, }} \\
\mathbf{m N / m}\end{array}$ & $\begin{array}{l}\Gamma_{\text {max }}, \mathbf{X 1 0}^{-11} \\
\mathbf{M o l . K}^{-1} \mathbf{c m}^{-1}\end{array}$ & $\begin{array}{c}\mathbf{A}_{\text {min }}, \\
\mathbf{n m}^{\mathbf{2}}\end{array}$ \\
\hline $\mathbf{B Q}_{\mathbf{1 0}}$ & 23.4 & 61.7 & 10.1 & 9.83 & 16.88 \\
\hline $\mathbf{B Q}_{\mathbf{1 8}}$ & 5.25 & 59 & 12.8 & 12.71 & 13.06 \\
\hline
\end{tabular}

Obviously, values of the (CMC) is dependent on the chemical structure of the surfactant Schiff base molecules ${ }^{(20)}$. The different (CMC) values of this surfactant depend on the hydrophobic moieties in its structure. Increasing the hydrophobic chain length, the number of repeated methylene group $\left(\mathrm{CH}_{2}\right)$ decreases the $(C M C)$ values generally as $\mathrm{BQ}_{10}$ and $\mathrm{BQ}_{18}$.

That effect could be explained on the view of the hydrophobicity of the molecules. Increasing of the hydrophobic chain length of the surfactant molecules, increases their non polar characters, resulting in increasing the repulsion forces between them and the polar water molecules (thermodynamically unstable). Hence, the molecules tend to lower that unfavorable situation via forming more stable aggregative structures which are micelles (thermodynamically stable). Therefore, the (CMC) occurred at lower concentration $^{(21)}$.

All the synthesized Schiff base metal complexes showed good solubility in aqueous medium. The complxation of the cationic Schiff base surfactant improves their surface tension. The surface tensions of the synthesized metal complexes were often decreased remarkably compared with their parent cationic Schiff base surfactant (Table 3).

Egypt. J. Chem. 55, No. 3 (2012) 
TABLE 3. Surface properties of the synthesized cationic Schiff bases metal complexes at $25^{\circ} \mathrm{C}$.

\begin{tabular}{|c|c|c|c|c|c|}
\hline Compound & $\begin{array}{c}\text { CMC, } \\
\text { mole/Lx10 }^{-7}\end{array}$ & $\begin{array}{c}\gamma_{\mathrm{cmc},} \\
\mathbf{m N} / \mathbf{m}\end{array}$ & $\begin{array}{l}\pi_{\mathrm{cmc}}, \\
\mathrm{mN} / \mathbf{m}\end{array}$ & $\begin{array}{l}\Gamma_{\max }, \mathbf{X 1 0}^{-11} \\
\text { Mol.K }^{-1} \mathbf{c m}^{-1}\end{array}$ & $\begin{array}{l}A_{\min }, \\
\mathbf{n m}^{2}\end{array}$ \\
\hline BQ10-Ni & 14 & 60 & 11.8 & 10.13 & 16.39 \\
\hline BQ18-Ni & 4.79 & 57.8 & 14 & 13.98 & 11.87 \\
\hline BQ10-Co & 35.5 & 62 & 9.8 & 7.06 & 23.5 \\
\hline BQ18-Co & 11.7 & 55.4 & 16.4 & 13.30 & 12.48 \\
\hline BQ10-Fe & 13.2 & 61.7 & 10.1 & 8.13 & 20.41 \\
\hline BQ18-Fe & 13.2 & 62.8 & 9 & 8.83 & 18.79 \\
\hline BQ10-Cu & 11.9 & 55.9 & 16.2 & 8.89 & 18.68 \\
\hline BQ18-Cu & 10 & 56.8 & 15 & 10.59 & 15.68 \\
\hline
\end{tabular}

Effectiveness $\left(\pi_{c m c}\right)$

The effectiveness if defined as the difference between the surface tension of the bidistilled water $\left(\gamma_{\mathrm{o}}\right)$ and that of the surfactant solution $\left(\gamma_{\mathrm{cmc}}\right)$ at the critical micelle concentrations is as follows:

$$
\pi_{\mathrm{cmc}}=\gamma_{\mathrm{o}}-\gamma_{\mathrm{cmc}}
$$

The values of $\pi_{\mathrm{cmc}}$ of the synthesized cationic Schiff bases were listed in Table 2. It is clear that the increasing of the hydrophobic chain length in surfactant molecule leads to increase the effectiveness at constant temperature as in surfactants $\left(\mathrm{BQ}_{10} \text { and } \mathrm{BQ}_{18}\right)^{(22)}$. Hence, the chemical structure of the hydrophobic moieties influences the effectiveness values of the surfactants under investigation. Increasing the carbon number of the hydrophobic structure, decreases the surface tension of the surfactant to lower extent, this is corresponded, by increasing the effectiveness value. The highest $\pi_{\mathrm{cmc}}$ value indicates the maximum surface activity of the surfactant within the same series. The effectiveness values are considered as a good variable in comparing between two surfactants in the same series.

But in case of Schiff base metal complexes when the metal is $\mathrm{Ni}^{++}$or $\mathrm{Co}^{++}$the effectiveness increase by increasing the hydrophobic chain length and the effectiveness can be arranged as the following $\mathrm{BQ}_{18} \mathrm{Ni}>\mathrm{BQ}_{10} \mathrm{Ni}$ and $\mathrm{BQ}_{18} \mathrm{Co}>$ $\mathrm{BQ}_{10} \mathrm{Co}$.And also in case of potatoes Schiff base metal complexes when the metal is $\mathrm{Fe}^{+++}$or $\mathrm{Cu}^{++}$the effectiveness decrease by increasing the hydrophobic chain length and the effectiveness can be arranged as the following $\mathrm{BQ}_{10} \mathrm{Fe}>$ $\mathrm{BQ}_{18} \mathrm{Fe}$ and $\mathrm{BQ}_{10} \mathrm{Cu}>\mathrm{BQ}_{18} \mathrm{Cu}$, (Table 3).

Maximum surface excess $\left(\Gamma_{\max }\right)$

The maximum surface excess $\left(\Gamma_{\max }\right)$ is defined as the concentration of the surfactant molecules at the air-water interface when that interface is completely 
covered by the surfactant molecules. The maximum surface excess $\left(\Gamma_{\max }\right)$ can be expressed as follows:

$$
\Gamma_{\max }=[(\partial \gamma) / d \log C] . R T
$$

where, $\partial \gamma=$ the difference in the surface tension in $\mathrm{mNm}^{-1}$,

$R=$ universal gas constant,

$T=$ absolute temperature

$(\partial \gamma) / d \log C$ is expressed as the surface pressure and describes both the pumping of surfactant molecules to the interface and into the bulk of the solution, i.e., at the equilibrium between singly adsorbed molecules at the interface and the micellized molecules in the aggregative structure (micelles).

The surface pressure increased by increasing the maximum surface excess of the surfactant molecules at the interface. The surface pressure increased by increasing the differences between the two surface tension values at very low concentration intervals. That is directly related to the ability of the surfactant molecules towards the adsorption at the air-water interfaces. By increasing the hydrophobic chain length of the surfactant molecules, the hydrophobicity increases ${ }^{(23)}$.

The maximum surface excess $\left(\Gamma_{\max }\right)$ of the synthesized Schiff base surfactants was represented in Table 2 at $25^{\circ} \mathrm{C}$. It is clear that the increasing of hydrophobic chain length (repeated methylene group) of the surfactant Schiff base molecules increases the $\left(\Gamma_{\max }\right)$. But also the maximum surface excess $\left(\Gamma_{\max }\right)$ of the metal complexes of Schiff base cationic surfactant increases by increasing the hydrophobic chain length with the same metal (Table 3).

Minimum surface area $\left(A_{\min }\right)$

The minimum surface area is defined as the area occupied by each surfactant molecule at the air-water interface of the surfactant solution at complete coverage or at the complete saturation and calculated as follows:

$A_{\text {min }}=10^{16} /\left[\Gamma_{\max } . N_{a v}\right]$

$A_{\text {min }}=$ minimum surface area in nanometer square $\left(\mathrm{nm}^{2}\right)$,

$\Gamma_{\text {max }}=$ maximum surface excess,

$N_{a v}=$ Avogadro's number $\left(6.023 \times 10^{23}\right)$.

The minimum surface area depends on many factors included in the molecular structures of surfactant ${ }^{(24)}$.

Polar groups increase the minimum surface area in the same manner. The hydrophobic chain length plays an important role in the $\mathrm{A}_{\min }$ values, that role can be explained as follow, when the hydrophobic chain length increases, the area occupied of this molecule at air-water interface increases. Therefore, minimum surface area of the synthesized Schiff base surfactant can be arranged as follows, $\mathrm{BQ}_{10}>\mathrm{BQ}_{18}$. In this case the opposite is true. But also the minimum surface area 
of the metal complexes of Schiff base cationic surfactant decrease by increasing the hydrophobic chain length with the same metal (Table 3).

\section{Thermodynamics of the synthesized Schiff base cationic surfactants}

The standard free energy of micellization and adsorption of the synthesized Schiff base surfactant and its free energy of their solution at $25^{\circ} \mathrm{C}$ can be calculated using the following thermodynamic equations ${ }^{(25)}$ :

$$
\begin{gathered}
\Delta \mathrm{G}_{\mathrm{mic}}=2.303 R T \log (\mathrm{CMC}) \\
\Delta \mathrm{G}_{\mathrm{ads}}=\Delta \mathrm{G}_{\mathrm{mic}}-\left(0.006 \mathrm{X} \pi_{\mathrm{cmc}} \times \mathrm{A}_{\text {min }}\right)
\end{gathered}
$$

Increasing the number of methylene groups in the hydrophobic chain length, increases its standard free energy of micellization ${ }^{(26)}$.

From Tables $4 \& 5$ it is clear that $\Delta \mathrm{G}_{\text {mic }}$ and $\Delta \mathrm{G}_{\text {ads }}$ of values of all synthesized Schiff bases surfactant are negative. The negativity of this values indicates the spontaneous behavior of two processes and this refers to the equilibrium between the two phases of the surfactant molecules (adsorbed and micellized phase) in their solutions at constant temperature $25^{\circ} \mathrm{C}$. Also, it is clear that, when the hydrophobic chain length of the synthesized Schiff bases surfactant increases $\Delta \mathrm{G}_{\text {mic }}$ and $\Delta \mathrm{G}_{\mathrm{ads}}$ increase. Also, the slight increase of $\Delta \mathrm{G}_{\mathrm{ads}}$ values may be ascribed to the tendency of the molecules to adsorb at the air-water interface until complete surface coverage and also the slight increase of $\Delta \mathrm{G}_{\text {mic }}$ values indicates the tendency of the surfactant molecules to migrate to the bulk of solution to form micelle. And also the negativity values of $\Delta \mathrm{G}_{\mathrm{ads}}$ are greater than the corresponding $\Delta \mathrm{G}_{\text {mic }}$. This indicates the tendency of surfactant molecules to be adsorbed at the air-water interface rather than escape to the bulk of their solutions.

TABLE 4. Thermodynamic properties of the synthesized cationic Schiff bases at $25^{\circ} \mathrm{C}$.

\begin{tabular}{|c|c|c|}
\hline Compound & $\Delta$ Gads & $\Delta$ Gmic \\
\hline $\mathbf{B Q}_{\mathbf{1 0}}$ & -8.71 & -7.69 \\
\hline $\mathbf{B Q}_{\mathbf{1 8}}$ & -9.57 & -8.57 \\
\hline
\end{tabular}

TABLE 5. Thermodynamic properties of the synthesized cationic Schiff bases metal

\begin{tabular}{|c|c|c|}
\hline Compound & $\Delta \mathbf{G}_{\mathrm{ads}}$ & $\Delta \mathbf{G}_{\text {mic }}$ \\
\hline $\mathrm{BQ}_{10}-\mathrm{Ni}$ & -9.15 & -7.99 \\
\hline $\mathrm{BQ}_{18}-\mathrm{Ni}$ & -9.62 & -8.63 \\
\hline $\mathrm{BQ}_{10}-\mathrm{Co}$ & -8.82 & -7.44 \\
\hline $\mathrm{BQ}_{18}-\mathrm{Co}$ & -9.32 & -8.10 \\
\hline $\mathrm{BQ}_{10}-\mathrm{Fe}$ & -9.26 & -8.03 \\
\hline $\mathrm{BQ}_{18^{-}} \mathrm{Fe}$ & -9.04 & -8.03 \\
\hline $\mathrm{BQ}_{10^{-}}-\mathrm{Cu}$ & -9.90 & -8.09 \\
\hline $\mathrm{BQ}_{18}-\mathrm{Cu}$ & -9.60 & -8.19 \\
\hline
\end{tabular}
complexes at $25^{\circ} \mathrm{C}$. 
Antimicrobial activity of the synthesized cationic Schiff base surfactant and its metal complexes against gram positive and gram negative bacterial strains, yeast, fungi and against sulfur reducing bacteria (SRB)

The biological activities of the synthesized cationic Schiff base $\left(\mathrm{BQ}_{10}\right.$ and $\mathrm{BQ}_{18}$ ) were evaluated for their antibacterial and antifungal potent actions against several known and highly cytotoxic bacterial, yeast and fungal strains including: Bacillus subtilis, Micrococcus sp, Pseudomonas aeruginosa, Sarcina sp, Candida albicans and Aspirgillus niger.

The results of the biocidal activities of the synthesized Schiff base surfactants were listed in Table 6 . The biocidal activity of these surfactants can be explained according to the diffusion mechanism. The adsorbed Schiff base amphiphiles on the cellular membranes ease the penetration of the nonpolar chains of these amphiphiles into these membranes. The charged head groups are also stabilized that penetration takes place by the interaction with the charges on these membranes. These charged either negative or positive charge depends on the bacterial genera (gram +ve/gram -ve). These charges appeared originally from the presence of teichoic acids or peptidoglycan in these membranes. The penetration of the hydrophobic chains within the bacterial or fungal cell membranes and the neutralization of their surface charge disturb their selective permeability towards the outer environment. That leads to the penetration of several components to the cellular cytoplasm including counter ions and combination occurs with the (nucleic acids) DNA and RNA. Hence, the biological reactions disturbed which causes death for these microorganisms. The synthesized Schiff base surfactants haven't got any biocidal activities on all bacterial, yeast and fungal strains, except $\mathrm{BQ}_{10}$ against Micrococcus sp and sarcina sp. ${ }^{(27)}$ (Table 6).

It is clear from the biocidal activity data that the metal complexes of these compounds exhibit higher biocidal activity than the parent schiff bases. That can be referred to the polarity nature of the Schiff bases in their cationic form. The quaternary ammonium Schiff bases contain pure positive charge on the nitrogen atom $\left(\mathrm{N}^{+}\right)$. The cellular membrane is highly sensitive towards these positively charged centers due to the hydrophobic nature of the membrane. So, these molecules are repelled even though these positive centers attached to the negative centers on the cellular membrane. It is observed from the biological study of the synthesized Schiff base metal complexes that they have higher activity than the free ligand.

Such phenomenon (increasing of the antimicrobial activity upon complexation) can be explained on the basis of Overtone's concept and chelation theory ${ }^{(28,29)}$. According to Overtone's concept of cell permeability the lipid membrane surrounded the microorganism cell favors the passage of only lipid soluble materials. On chelation theory basis, the polarity of the metal ion is reduced to a greater extent due to the overlap between the ligand orbital and partial sharing of the positive charge of the metal ion with donor groups. Further,

Egypt. J. Chem. 55, No. 3 (2012) 
it increases the delocalization of $\pi$-electrons over the whole chelate ring and enhances the lipophilicity of the complex. The higher lipophilicity enhances the penetration of the complexes into lipid membranes and blocking of metal binding sites on the enzymes of the microorganism. As a result, the biocidal activity of the Schiff base metal complexes increased than their parent compounds.

Another factor was concluded to increase the antimicrobial activity of the synthesized Schiff base metal complexes which is the presence of the transition metal ion in their chemical structures. The metal ions, in their nature are considered a highly potent element due to their tendency towards complexation with the biological components in the cytoplasm.

The metal complexes of Schiff base surfactant have bacterial activity on Micrococcus sp. But $\mathrm{BQ}_{10}$ and its metal complexes have also bacterial activity on Sarcina sp. But all these metal complexes haven't got any biocidal activity on the yeast and fungi (Table 7).

The petroleum industries including: exploring, refining, transporting and storing are suffering from the destructive activity of the sulfur reducing bacteria. That is due to this type of bacteria reduces the sulfur containing compounds (widely spread in the unrefined oil) to $\mathrm{H}_{2} \mathrm{~S}$. The $\mathrm{H}_{2} \mathrm{~S}$ is corrosive for the carbon steel fabricates and causes their destruction and deterioration. Hence, the biocides for sulfur reducing bacteria are considered the third consumed compound in the petroleum sector.

The synthesized cationic Schiff base amphiphiles were evaluated for their cytotoxic action against Desulfomonas pigra as known and spreading sulfur reducing bacterial genera (Table 6).

From this table we conclouded that, the hydrophobic chain length of the synthesized cationic Schiff base amphiphiles has an important influence on the biocidal activity against tested strain of $(\mathrm{SRB})^{(30)}$. This behavior is the same behavior against gram negative and gram positive bacteria. The sulfur reducing bacteria (as a potent type of gram negative bacteria) are characterized by thick cellular membrane which acquires these microorganisms high resistance against wide range of biocides. When the hydrophobic chain length of the synthesized compounds increases, the inhibition zone diameter decreases and therefore the biocidal activity against (SRB) decreases that referred to when the hydrophobic chain length decreases the number of adsorbed molecule at the cell membrane interface increases and this leads to increase their potent biocidal action.

From Table 7, it is clear that, when the hydrophobic chain length of the synthesized Schiff base metal complexes decreases the inhibition zone diameter increases (biocidal activity against sulfur reducing bacteria increases with the same metal and this referred to the same previous reason). 
In some cases the complexation of the parent amphiphiles Schiff base increases their biocidal activity against sulfur reducing bacteria, as the complexation of $\mathrm{BQ}_{18}$ with $\mathrm{Fe}^{3+}$ and $\mathrm{Cu}^{2+}$ metals. But no change occurs in the biocidal activity against sulfur reducing bacteria in the comlexation of $\mathrm{BQ}_{18}$ with $\mathrm{Fe}^{2+}$ and $\mathrm{Cu}^{2+}$ metals.

The results of the biocidal activity of the synthesized metal complexes showed two cytotoxic features. First, the complexation of the synthesized cationic Schiff bases with different transition metal ions increased their biocidal activities against Desulfomonas pigra. That can be referred to the fact that cellular membrane is highly sensitive to the positive or negative charges. Hence, their penetration into the cellular constituents is restricted by the selective permeability of these membranes. Second, the type of metal ion in the complex molecules plays an important role in enhancing the cytotoxicity of these metal complex biocides. That can be refereed to the electronegativity and the ionic radius of the transition metals under consideration.

The best biocide activities against $(\mathrm{SRB})$ are $\mathrm{BQ}_{10} \mathrm{Cu}$ and $\mathrm{BQ}_{10} \mathrm{Co}$.

TABLE 6. Antimicrobial activities of the synthesized potatoes cationic Schiff base surfactants against gram positive, gram negative bacteria, yeast, fungi and Desulfomonas pigra.

\begin{tabular}{|c|c|c|c|c|c|c|c|}
\hline \multirow{3}{*}{ Compounds } & \multicolumn{4}{|c|}{ Bacteria } & \multirow{3}{*}{$\begin{array}{c}\text { Yeast } \\
\begin{array}{c}\text { Candida } \\
\text { albicans }\end{array}\end{array}$} & \multirow{3}{*}{$\begin{array}{c}\text { Fungi } \\
\begin{array}{c}\text { Aspergillus } \\
\text { niger }\end{array}\end{array}$} & \multirow{3}{*}{$\begin{array}{c}\text { Desulfomonas } \\
\text { pigra } \\
(\mathrm{mm} / \mathrm{mg}\end{array}$} \\
\hline & \multicolumn{2}{|c|}{ Gram positive } & \multicolumn{2}{|c|}{ Gram negative } & & & \\
\hline & $\begin{array}{l}\text { Bacillus } \\
\text { subtilis }\end{array}$ & $\begin{array}{l}\text { Micrococcus } \\
\text { sp. }\end{array}$ & $\begin{array}{c}\text { Pseudomonas } \\
\text { aeruginosa }\end{array}$ & $\begin{array}{l}\text { Sarcina } \\
\text { sp. }\end{array}$ & & & \\
\hline $\mathbf{B Q}_{10}$ & 0 & 25 & 0 & 24 & 0 & 0 & 15 \\
\hline $\mathrm{BQ}_{18}$ & 0 & 0 & 0 & 0 & 0 & 0 & 10 \\
\hline
\end{tabular}

TABLE 7. Antimicrobial activities of the synthesized cationic Schiff base metal complexes against gram positive, gram negative, yeast, fungi and Desulfomonas pigra.

\begin{tabular}{|c|c|c|c|c|c|c|c|}
\hline \multirow{3}{*}{ Compounds } & \multicolumn{4}{|c|}{ Bacteria } & \multirow{3}{*}{$\begin{array}{c}\text { Yeast } \\
\begin{array}{c}\text { Candida } \\
\text { albicans }\end{array}\end{array}$} & \multirow{3}{*}{\begin{tabular}{|c|} 
Fungi \\
$\begin{array}{c}\text { Aspergillus } \\
\text { niger }\end{array}$ \\
\end{tabular}} & \multirow{3}{*}{$\begin{array}{c}\text { Desulfomonas } \\
\text { pigra } \\
(\mathrm{mm} / \mathrm{mg}\end{array}$} \\
\hline & \multicolumn{2}{|c|}{ Gram positive } & \multicolumn{2}{|c|}{ Gram negative } & & & \\
\hline & $\begin{array}{c}\text { Bacillus } \\
\text { subtilis }\end{array}$ & $\begin{array}{l}\text { Micrococcus } \\
\text { sp. }\end{array}$ & $\begin{array}{c}\text { Pseudomonas } \\
\text { aeruginosa }\end{array}$ & Sarcina sp. & & & \\
\hline $\mathrm{BQ}_{10}-\mathrm{Ni}$ & 0 & 24 & 0 & 22 & 0 & 0 & 14 \\
\hline$B Q_{18}-\mathrm{Ni}$ & 0 & 18 & 0 & 0 & 0 & 0 & 0 \\
\hline $\mathrm{BO}_{10^{-}} \mathrm{Co}$ & 0 & 23 & 0 & 0 & 0 & 0 & 15 \\
\hline $\mathrm{BQ}_{18^{-}} \mathrm{Co}$ & 0 & 18 & 0 & 0 & 0 & 0 & 0 \\
\hline $\mathrm{BQ}_{10^{-}} \mathrm{Fe}$ & 0 & 21 & 0 & 20 & 0 & 0 & 14 \\
\hline $\mathrm{BQ}_{18^{-}} \mathrm{Fe}$ & 0 & 0 & 0 & 0 & 0 & 0 & 14 \\
\hline $\mathrm{BQ}_{10^{-}} \mathrm{Cu}$ & 0 & 22 & 0 & 0 & 0 & 0 & 15 \\
\hline $\mathrm{BQ}_{18^{-}} \mathrm{Cu}$ & 0 & 0 & 0 & 0 & 0 & 0 & 12 \\
\hline
\end{tabular}




\section{References}

1. Kumar, Y., Rathish, V., Mayur, N., Balnjab, S. and Chandaa, S., Serb. J. Chem. Soc. 69, 991-998 (2004).

2. Penna. V.T., Martins S.A. and Mazola P.G., BMC Public Health, 15, 2 (2002)

3. Rao, S. and Mitra A.S., J. Ind. Chem. Soc. 55,420 (1978).

4. Negm, N. A., Elkholy, Y. M., Ghuiba, F. M. and Zahran, M. K. et al., Benzothiazol3-ium cationic Schiff base surfactants: Synthesis, surface activity and antimicrobial applications against pathogenic and sulfur reducing bacteria in oil fields. J. Disp. Sci Technol. 32, 512-518 (2011).

5. Pe 'rez, L., Pinazo, A., Garcı 'a, M. T. and Lozano, M. et al., Cationic surfactants from lysine: Synthesis, micellization and biological evaluation. Eur. J. Med. Chem. 44, 1884-1892 (2009).

6. Pernak, J., Mirska, I. and Kmiecik, R., Antimicrobial activities of new analogues of benzalkonium chloride. Eur. J. Med. Chem. 34, 765-771(1999).

7. Negm, N. A., Zaki, M. F. and Salem, M. A. I., Antibacterial and antifungal activitiessurface active properties relation of novel di-Schiff base cationic Gemini amphiphiles bearing homogeneous hydrophobes. J. Disp. Sci. Technol. 31, 1390-1395 (2010).

8. Parekh, J., Inamdhar, P., Nair, R., Baluja, S. and Chanda, S. J. Serb. Chem. Soc. 70, 1161 (2005).

9. Vaghasia, Y., Nair, R. and Soni, M., Baluja, S. and Chanda, S., J. Serb. Chem. Soc. 69, 991 (2004).

10. Sun, F., Sun, R. and Sun, J.X., Journal of Agriculture Food Chemistry, 50 (22), 6428-6433 (2002).

11. Erk, B., Baran, A.Y. and Balaban, A., Synthesis and Reactivity in Inorganic and Metalorganic Chemistry, 10, 30 (2000).

12. Zaky, M.F., Synthesis, surface properties and biocidal activity of 2-amino 1-naphthol4-sulfonate triethanol amine mono alkanoate cationic surfactants. Egypt. J. Petrol. 17 (1), 21-51 (2008).

13. Negm, N.A., El-Farargy, A., Zaki, M.F., Mahmoud, S.A. and Abdel Rahman, N., Egyptian Journal of Petroleum, 17(2),15-25(2008).

14. Negm, N.A. and Zaki, M.F., Colloids and Surfaces B: Biointerfaces, 64, 179-183 (2008).

15. Zaki, M. and Negm, N., Novel nonionic Schiff bases antimicrobial and surface activity. Chemistry Today (in press) (2012).

16. Tao, Z., Zhang, S., Li and Hou, B., Corrosion Science, 51, 2588 (2009). 
17. Behpour, M., Ghoreishi, S.M., Soltani, N. and Niasari, M.S., Corrosion Science, 51, 1073 (2009).

18. Zhang, B.Q. and Hua, Y.X., Electrochimica Acta, 54, 1881 (2009).

19. Zhang, S., Tao, Li and Hou, Applied Surface Science, 255, 6757 (2009).

20. Abboud, Y., Abourriche, A., Saffaj, T., Berrada, M., Charrouf, M., Bennamara, A. and Hannach, H., Desalination, 237, 175 (2009).

21. Negm, N.A., Surface activities and electrical properties of long chain diquaternary bola-form amphiphiles. Egypt. J. Chem. 45, 483-499 (2002).

22. Quraishi, M.A. and Shukla, S.K., Material Chemistry and Physics, 113, 685 (2009).

23. Tang, Y.M., Yang, W.Z., Yin, X.S., Liu, Y., Wan, R. and Wang, J.T., Materials Chemistry and Physics, 116, 479 (2009).

24. Hamid, S. M. and Sherrington, D.C., Brit. Polymer J. 16, 39 (1984).

25. Negm, N. A., Salem, M. A. I., Badawi, A. M. and Zaki, M. F., Ain Shams Science Bulletin, 41, 1 (2003).

26. Negm, N. A., Mohamed, A. A. and El-Awady, M. Y., Egyptian Journal of Chemistry, 47(4), 369 (2004).

27. Negm, N. A., Morsy, S. M. I. and Said, M. M., Pyrazole derived cationic surfactants and their tin and copper complexes: synthesis, surface activity, antibacterial and antifungal efficiency. J. Surf. Deterg. 13, 521-528 (2010).

28. Raman, N., Muthuraj, V., Ravichandran, S. and Kulandaisamy, A., Proc. Indian Acad. Sci. (Chem. Sci.), 115 (3), 161 (2003).

29. Tweedy, B. G., Phytopathology, 55, 910 (1964).

30. IsmAiad, I.A., Badawi, A.M., El-Sukkary, M.M., El-Sawy, A.A. and Adawy, A.I., Synthesis and biocidal activity of some naphthalene- based cationic surfactants. $J$. Surf. Deterg. 15, 223-234 (2012). 
التخليق والتوصيف والنشاط المضاد للحيوية لقواعد شيف التفيف الكاتيونية ذات النشاط السطحي عديدة السكريات (المستخلصة من النئن البطاطس) ومتر اكباتها القلزية البطية

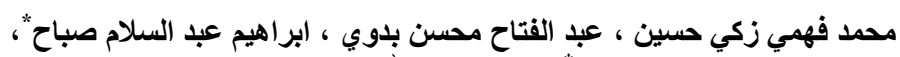

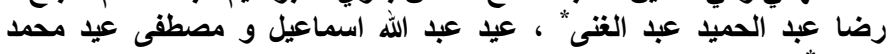
* زندوي

قسم البنروكيمياويات - معهد بحوث البترول و *كلية العلوم - جامعة الأزهر -

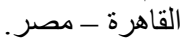

• تعتبر المواد ذات النشاط السطحي الكاتيونيـة من أهم المواد التى لهـا تطبيقيات

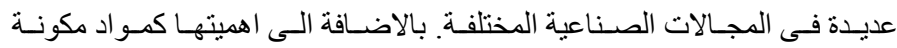

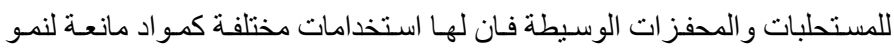

$$
\text { البكتريا و الفطريات. }
$$

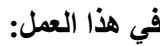

• تم سلفتة عديد سكريات البطاطس للحصول على كبريتات عديد السكريات.

• تم تحضير قاعدتين من قو اعد شيف بتفاعل 4-بيريدين كربوكسالدهيد مـع ديسيل أمين و أوكتاديسيل أمين. • تم تحضير أملاح الأمونيوم الرباعية بتفاعل قو اعد شيف المحضرة مـع كبريتات عديد السكريات. • تـم تحضـير المتر اكبـات الفلزيـة للمركبـات الكاتيونيـة المحضـرة بتفاعلهـا مـع

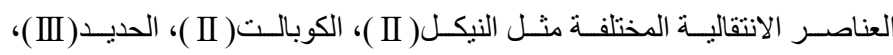
النحساس( II ) بنسبة 2 مـول مـن المركب الكاتيوني الـى مـول واحــ مـن العنصـر الانتقالي. • تم اثبات التركيب الكيميائي لقو اعد شيف الكاتيونية ومنر اكباتها باستخدام التحاليل الكمية العنصرية وطيف الاشعة تحت الحمر اءو الرنين النووى المغناطيسى لذرات الهيدروجين وطيف الأشعة فوق البنفسجية والامتصاص الذري.

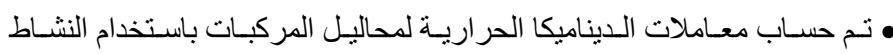
السطحي لها.

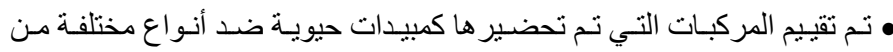
البكتيريـا و الخمـائر و الفطريـات وكذللك تـم اختبـار هـذه المركبـات كمبيـدات لنمـو البكتيريا المختزلة للكبريتات في المو اد البترولية. 